\title{
Submerged macrophyte biomass distribution in the shallow saline lake Fuente de Piedra (Spain) as function of environmental variables
}

\author{
Rafael M. Conde-Álvarez ${ }^{1 *}$, Elena Bañares-España² José M. Nieto-Caldera², \\ Antonio Flores-Moya ${ }^{2} \&$ Félix L. Figueroa ${ }^{3}$ \\ ${ }^{1}$ EFYVE (Estudios de flora y vegetación S.L.), c/ Corregidor Nicolás Isidro, Edif. Mercurio n ${ }^{7}$ 7, oficina 19, E-29004 Málaga, Spain \\ ${ }^{2}$ Departamento de Biología Vegetal (Botánica), Facultad de Ciencias, Universidad de Málaga, E-29071 Málaga, Spain \\ Departamento de Ecología y Geología, Facultad de Ciencias, Universidad de Málaga, E-29071 Málaga, Spain \\ rconde@efyve.com; elbaes@uma.es; nieto@uma.es; floresa@uma.es; felix_lopez@uma.es
}

\begin{abstract}
Conde-Álvarez, R.M., Bañares-España, E., Nieto-Caldera, J.M., FloresMoya, A. \& Figueroa, F.L. 2012. Submerged macrophyte biomass distribution in the shallow saline lake Fuente de Piedra (Spain) as function of environmental variables. Anales Jard. Bot. Madrid 69(1): 119-127.

Aquatic macrophyte biomass, diaspore bank distribution and their relationship to spatial variability of depth, nutrients (nitrite, nitrate, ammonium and soluble reactive phosphorus) as well as sediment granulometry in an athalassohaline lake have been studied during one wet hydrological year. The results indicate that species growing in the lake show different spatial distribution patterns throughout the lake. Indirect gradient analysis (canonical analysis) results showed a first axis defined as a function of Ulva flexuosa Wulfen biomass which is, in turn, positively correlated with interstitial ammonium and Soluble Reactive Phosphorus (SRP). The second axis was mainly established due to Lamprothamnium papulosum (Wallr.) J. Groves biomass which correlated positively to depth and negatively to interstitial ammonium and SRP. These results revealed a NESW eutrophic gradient allowing the $U$. flexuosa biomass proliferation. This phenomenon could increase the shadow effect over the rest of the macrophytes inhabiting this shallow lake. Moreover, the eutrophic harmful effect on the macrophyte physiology and over the diaspore bank could have important consequences in the survival of such important populations. The results reported in this study show the need for studies as the base to select sampling points for monitoring this wetland.
\end{abstract}

Keywords: submerged macrophytes, eutrophication, lakes, maps, Fuente de Piedra, Spain.

\section{INTRODUCTION}

A great number of ecological, social and even economic reports on the conservation of wetlands have been presented in the last century (Turner \& al., 2000). In spite of the programs to conserve wetlands, these ecosystems continue to be degraded to different extents (Fraser \& Keddy, 2005). In Europe, during the last few years several studies have focussed on developing indices or indicators for assessing lake water quality based on composition and abundance of

\section{Resumen}

Conde-Álvarez, R.M., Bañares-España, E., Nieto-Caldera, J.M., FloresMoya, A. \& Figueroa, F.L. 2012. Distribución de la biomasa de los macrófitos sumergidos en la laguna salina somera de Fuente de Piedra (España) en función de las variables ambientales. Anales Jard. Bot. Madrid 69(1): 119-127 (en inglés).

La distribución de la biomasa de los macrófitos acuáticos y de su banco de semillas y oogonios ha sido investigada en relación a la profundidad, los nutrientes (nitrito, nitrato, amonio y fósforo soluble reactivo) y la granulometría del sedimento durante un año hidrológico húmedo. Los resultados muestran patrones de distribución diferentes en las distintas especies. Los resultados del análisis canónico basado en análisis de gradiente indirecto muestran un primer eje definido en función de la biomasa de Ulva flexuosa Wulfen que, a su vez, está positivamente correlacionada con el amonio intersticial y el fosfato soluble. El segundo eje se establecía principalmente en función de la biomasa de Lamprothamnium papulosum (Wallr.) J. Groves, que a su vez estaba positivamente relacionada con la profundidad y negativamente correlacionada con el amonio intersticial y el fosfato soluble. Estos resultados ponen de manifiesto un gradiente NE-SW de eutrofización que induce la proliferación de U. flexuosa, lo que podría contribuir a aumentar el efecto de sombreo sobre el resto de los macrófitos de la laguna. Además la eutrofización puede ejercer un efecto negativo tanto en la fisiología de los macrófitos como sobre el banco de diásporas poniendo en riesgo la supervivencia de estas poblaciones. Los resultados obtenidos en el presente estudio resaltan la necesidad de disponer de estudios de base para seleccionar los puntos de muestreo necesarios para monitorizar este tipo de humedales.

Palabras clave: macrófitos sumergidos, eutrofización, laguna, mapas, Fuente de Piedra, España.

macrophytes (Moe \& al., 2008; Penning \& al., 2008b; McElarney \& Rippey, 2009). However, the use of quantitative measurements including replicates is less common (McElarney \& Rippey, 2009; Søndergaard \& al., 2010). In parallel, other studies have focussed on carrying out intercalibration processes between different sampling protocols and the used indexes (Foden, 2007). Less attention, however, has been paid to the selection of appropriate sampling sites for monitoring system in order to control the spatial system variability. 
While most of these studies have been focussed in freshwater lakes (Moe \& al., 2008; Penning \& al., 2008a; McElarney \& Rippey, 2009), less attention has been paid to freshwater brackish and saline wetlands that are seasonally or intermittently flooded, in spite of the lack in available information about these systems (Ramsar, 2007). In the case of inland wetland from the Iberian Peninsula record of macrophytes species has been used to assess the botany value of wetland (Cirujano \& al., 1992). This study only took into account regional or local scales, but more accurate studies using spatial fine scales and adequate sampling protocols considering the potentially relevant range of space (Pérez-Ruzafa \& al., 2007) are necessary to test the existence of general patterns in the system (Anderson \& al., 2005). The use of fine scale mapping of wetlands is useful for analysing variability within individual wetlands and assessing the source of variability (Feldmann \& Nõges, 2007). This factor is relevant for a suitable management, conservation or restoration of these areas (Baker \& al., 2006). Aquatic macrophyte distribution has been related to many different environmental factors (Pokorný \& Kevět, 2004). Nevertheless, nowadays it is commonly accepted that nutrient enrichment is one of the factors which have more influence on aquatic macrophytes (Van den Berg \& al., 1999).

Fuente de Piedra lake is a shallow temporally athalassohaline lake situated in Southern Spain $\left(37^{\circ} 06^{\prime} \mathrm{N}, 04^{\circ} 45^{\prime} \mathrm{W}\right)$ covering $13.5 \mathrm{~km}^{2}$ of land surface. This wetland is declared a protected site (Natural reserve). The main water input to the basin lake is by ground-water inflow, although it is also fed by two streams (Santillán \& Charcón; Fig. 1) and by surface runoff through the farmland which is around the lake. Discharges of nutrient-rich waters in the north-eastern part of the lagoon took place by Charcón stream in the past. Olive mill wastewater (OMW) generated by the olive oil extraction and untreated waste water were discharged to this stream, introducing high levels of nutrient in the lake (Vargas \& al., 1983). Although, this problem was solved with the prohibition and control of OMW discharges and purifying wastewater from nearby towns, this stream continued flowing into the lagoon waters rich in nutrients (GarcíaJiménez, 1991; Conde-Álvarez, 2001).

Several studies have recorded the submerged species growing in the lake as well as general descriptions of the different components of this aquatic system but they were carried out only in a sharply demarcated area of the lake (García-Jiménez, 1991). Moreover, no previous attention had been paid to the diaspore bank which plays an important ecological role as constitutes the initial stage after the summer drought.

Our aims were: (1) to characterize the spatial distribution as a function of depth (light availability), nutrient content in the water column and in sediment interface, and sediment granulometry. (2) To assess the relationship between macrophyte biomass and diaspore bank distribution. (3) To highlight the factors to be taken into account in order to facilitate the selection of sampling points for an adequate monitoring programme.

\section{MATERIALS AND METHODS}

\section{Sampling sites}

The lake surface was divided by a regular grid of $60 \mathrm{sam}$ pling point situated every $500 \mathrm{~m}$ (Fig. 1) by means of 1:5000 scaled geo-referenced photograph, using Arcview 3.1 software. According to the Natural Reserve Direction, sampling in the SW zone of the lake was forbidden in order to avoid disturbance in a reproductive colony of pink flamingos (Phoenicopterus ruber roseus). A Differential Global Positioning System (DGPS) composed of a receiving device TRIMBLE AgGPS 132 and a navigation system HYPACK Coastal Oceanographic was used to position sampling sites in situ.

\section{Field data collection}

The field surveys were conducted between $8^{\text {th }}$ June and $15^{\text {th }}, 1998$, coinciding with the maximum macrophyte biomass in the lake (Conde-Álvarez, 2001). The minimum sampling area was established the previous week in a zone of the lake with presence of all macrophytes. As a result of this study, a surface of $0.1764 \mathrm{~m}^{2}(0.42 \times 0.42 \mathrm{~m})$ was chosen as an adequate sampling area, 3 samples of squares assured a coefficient of variation $<40 \%$. At each sampling point, all macrophytes (including the roots) growing within 3 replicates $0.42 \times 0.42 \mathrm{~m}$ quadrants were collected. Samples were

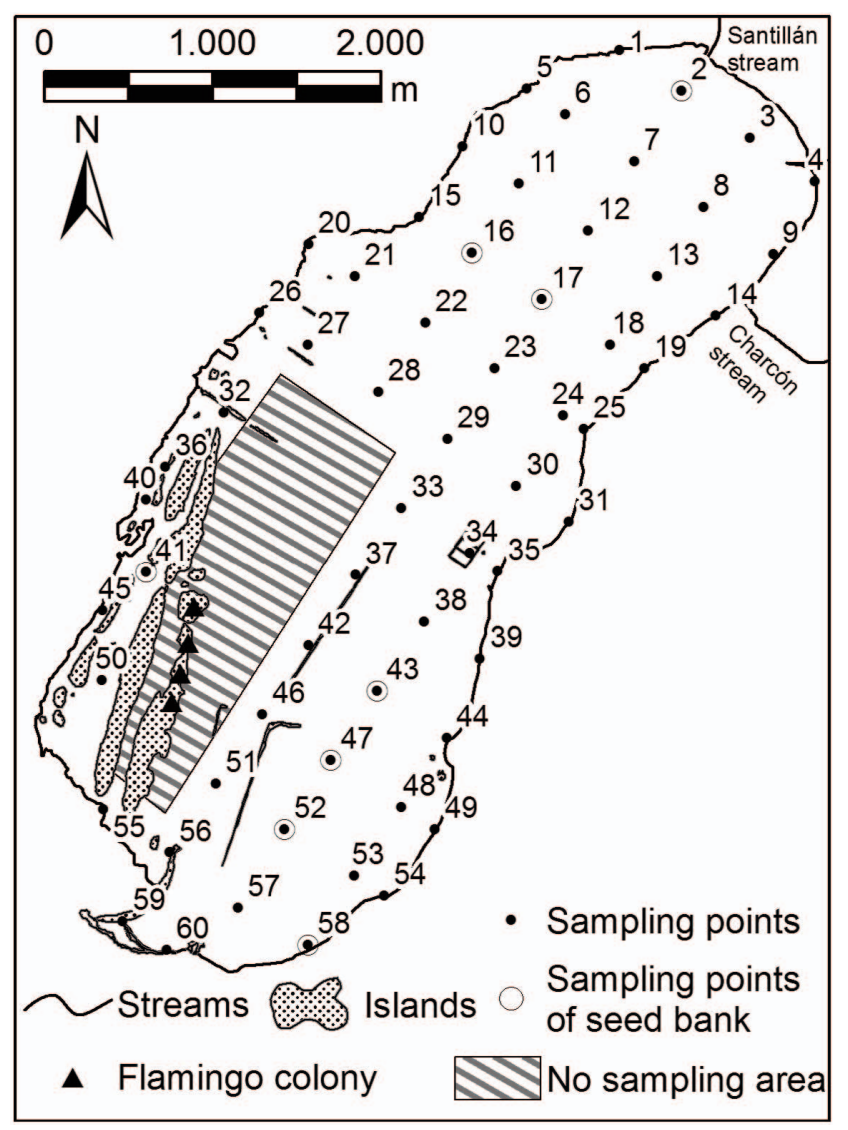

Fig. 1. Sampling points distribution in the shallow saline lake Fuente de Piedra. 
cleaned of epiphytes and sediments, identified to species, dried $\left(70{ }^{\circ} \mathrm{C}\right.$ for $\left.48 \mathrm{~h}\right)$ and weighed at the end of every day.

Water samples for nutrient analysis were collected by submersing $150 \mathrm{ml}$-bottles; the water was filtered through Whatman GF/C (1.2 $\mu \mathrm{m})$ fibre filter and kept at $-20 \pm 1{ }^{\circ} \mathrm{C}$ until the analysis. Sediment samples for interstitial water nutrient analyses were taken in triplicate, using $5 \mathrm{~cm}$-diameter cores, which were inserted $5 \mathrm{~cm}$ into the sediment. These cores were covered at both ends and frozen until their processing. Sediment samples for particle size analysis were taken using different $10 \mathrm{~cm}$-diameter cores, which were inserted $5 \mathrm{~cm}$ into the sediment. These samples were dried and stored until processing. A hand refractometer device (Atago, Japan) was used for salinity determination. Depth of the water column was also measured.

In addition, 8 sampling points (Fig. 1) were used to study the relationships between macrophyte biomass and diaspore bank (seeds and oogonies). These sampling points were selected after analysing the macrophyte biomass distribution. Samples were collected in September 1998 once the macrophytes had disappeared and the seeds were in the sediment. The diaspore bank at each sampling point was characterized by collecting 5 replicated $10 \mathrm{~cm}$-diameter cores, which were inserted $5 \mathrm{~cm}$ into the sediment. The sediment content in each core was elutriated with a jet of water through sieves of 2, 1, 0.5, 0.25 and $0.1 \mathrm{~mm}$ of aperture mesh. These 3 fractions were inspected under an optical microscope. All seeds in the residue were counted, while in the case of oogonies subsamples of the residue were taken by use of riffle splitter, which is commonly employed to improve sub-sampling precision in studies of foraminifera and other small fossils.

\section{Analyticalmethods}

Nutrient analyses were carried out with a Technicon Traacs 800TM Autoanalyzer (Technicon Instruments Corporation, USA). Nitrate and nitrite analyses were performed according to the Industrial Method $N^{\circ}$ 818-87T based on Shinn (1945) and Wood \& al. (1967), respectively. Ammonium ion was analysed using the Industrial Method N ${ }^{\circ} 786-86 \mathrm{~T}$ (Slawyk \& MacIsaac, 1972). Soluble reactive phosphorus (SRP) was determined using the malachite green method (Fernández \& al., 1985). Granulometric data were obtained through sieving to separate sands and pipette analysis (Porta, 1986) to separate silts and clays. Grain size categories were 2000-50 sands, 65-2 $\mu \mathrm{m}$ silt and $<2 \mu \mathrm{m}$ clay.

\section{Data analyses}

Isoline mapping of different variables were obtained by using interpolation methods based on natural neighbour algorithms. For this purpose, Spatial Analyst (an extended module of ARCGIS 8.3) was used.

The relationships between species biomass data and environmental variables were assessed by the use of canonical analysis method based in indirect gradient analysis. In this multivariate proceeding ordination derived solely from species data, while environmental data are then used to in- terpret the ordination Legendre \& Legendre (1998). Thus, Principal Component Analysis (PCA) was used to determine the major patterns of variation within the species biomass data. Then Environmental variables were used to interpret biomass distribution patterns of all species. Dutilleul's modified t-test for correlations were also used to assess the relationship between the species data and the environmental variables by using PASSAGE software (Rosenberg \& Anderson, 2011). All Multivariate analyses were carried out in accordance with Sokal \& Rohlf (1995) and Legendre \& Legendre (1998) using the computer programs CANOCO 4.0 and SPSS 12.

\section{RESULTS}

\section{Spatial variations of biomass}

Seven different species, belonging to different taxonomic groups were found in the lake. Except for the green algae Ulva flexuosa Wulfen, records of the remaining species had been reported previously in the lake. Ulva flexuosa was the species with the highest values of biomass, exceeding $120 \mathrm{~g}$ DW $\mathrm{m}^{-2}$ in the northwest part of the lake (Fig. 2a), with a peak of $189 \pm 18 \mathrm{~g} \mathrm{DW} \mathrm{m}^{-2}$ near the mouth of the Charcón stream. In contrast, the alga was not present in the southwest of the lake. Another widely distributed species in the lagoon is the angiosperm Althenia orientalis (Tzvelev) García Murillo \& Talavera (Fig. 2b). This species was present throughout the lake, with the exception of a zone situated in the Northwest, where U. flexuosa biomass values were higher than $150 \mathrm{~g} \mathrm{DW} \mathrm{m}^{-2}$. The maximum values of $A$. orientalis biomass $\left(85 \pm 24 \mathrm{~g} \mathrm{DW} \mathrm{m}^{-2}\right.$ at sampling point 27$)$ were obtained in the central part of lake. On the other hand, biomass values lower than $1 \mathrm{~g} \mathrm{DW} \mathrm{m} \mathrm{m}^{-2}$ were obtained in the south zone. In the case of Ruppia drepanensis Tineo ex Guss. a dense bed of plants was found both on the southwest side (among islands) and the southeast shore (Fig. 2c), with values of plant biomass around $40-50 \mathrm{DW} \mathrm{m}^{-2}$ in both zones. In the rest of the lake this species was absent or present as scattered plant patches. Ruppia maritima L. was found in shore areas both in the north (sampling point 1: $3.3 \pm 2.9 \mathrm{~g} \mathrm{DW} \mathrm{m}^{-2}$ ) and the southwest points (e.g. sampling point 40: $40 \pm 18 \mathrm{~g} \mathrm{DW} \mathrm{m}^{-2}$ ).

The charophyte Lamprothamnium papulosum (Wallr.) J. Groves showed a more localized distribution (Fig. 2d). This species formed a dense monospecific bed, with high biomass values (e.g. sample point 46:119 $\pm 36 \mathrm{~g} \mathrm{DW} \mathrm{m}^{-2}$ ) in the central part of the south side of the lake. This charophyte was also present together with $A$. orientalis and $R$. drepanensis in other areas of the lake. In addition, some deteriorated individuals of Chara and a few specimens of the aquatic liverwort Riella belicophylla (Bory \& Mont.) Mont. were found at the sampling points $(38,43)$ and $(57,59)$, respectively.

\section{Spatial variations of environmental variables}

The deepest areas were located around the mayor axis of the central part of the lake, with a maximal depth of $111 \mathrm{~cm}$ measured in the sampling point 43 (Fig. 3a). Maximal land 


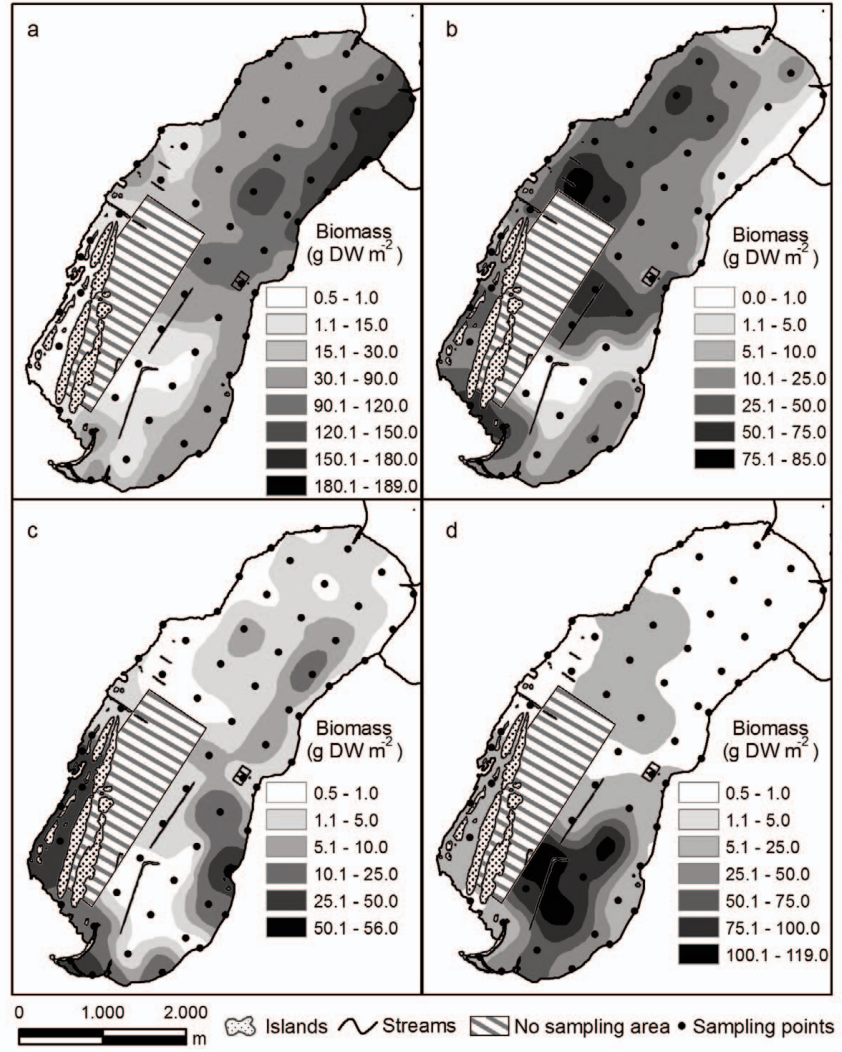

Fig. 2. Biomass distribution of Ulva flexuosa (a), Althenia orientalis (b), Ruppia drepanensis (c) and Lamprothamnium papulosum (d) in Fuente de Piedra lake.

slopes were situated in the east and west while the slightest slope was situated in the northern side. In any case, the whole lake basin is mostly flat.

The clay size particles represented less than $5 \%$ (Fig. $3 \mathrm{~b})$, while the silt was the predominant particle size $(<90$ $\%$ ) in most parts of the lake (Fig. 3c). Nevertheless, some areas of the lake showed a high content of sand. This is the case of the northern side, near mouths of streams, where sand content was higher than $12 \%$, with a maximum content of sand $(75 \%)$ in the sampling point 19 (Fig. 3d). Moreover, in the southern part a strip with about $12 \%$ of sand content was also located.

The water concentration of SRP showed values lower than $0.25 \mu \mathrm{M}$ in most of the lake surface (Fig. 4a). Although, a higher concentration was measured for water of the Northeastern side near the mouth of the stream, and especially in the case of the water located among the islands situated in the northwest side (e.g. $0.8 \pm 0.01 \mu \mathrm{M} \mathrm{PO}_{4}{ }^{3}$ obtained at sampling point 36). The interstitial water concentration of SRP showed values higher than those of the water column. In this case a decreased concentration gradient in the northeast-south direction was observed (Fig. 4b), with the maximum values near mouths of streams present in the northeast side $\left(52 \pm 0.01 \mu \mathrm{M} \mathrm{PO}_{4}{ }^{3-}\right.$ at the sampling point 9). In contrast, values lower than $1 \mu \mathrm{MPO}_{4}{ }^{3-}$ were measured for interstitial water of the southern side. Water ammonium content was higher in the southern part of the lake (1.4 - 2.7

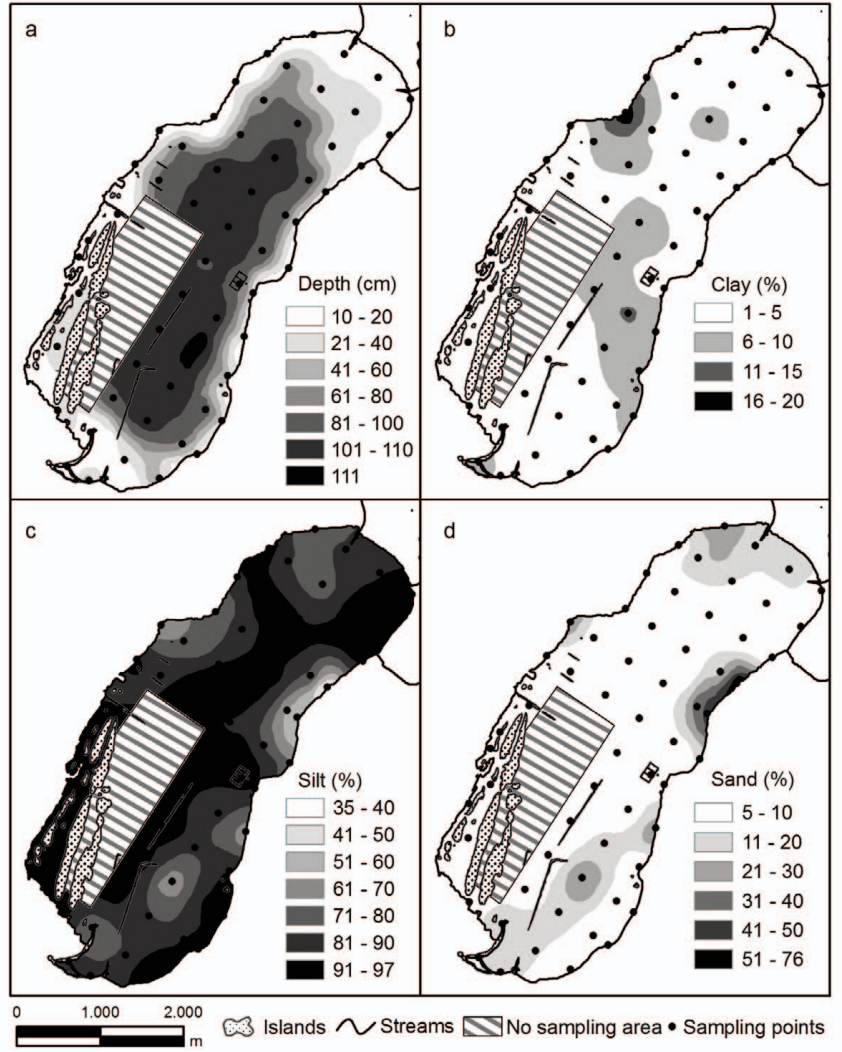

Fig. 3. Distribution of water depth (a), and sediment content of: clay (b), silt (c) and sand (d) in the Fuente de Piedra lake.

$\mu \mathrm{M})$ than in the northern side $(0.2-1.6 \mu \mathrm{M})$ (Fig. 4c). In the case of interstitial water ammonium concentration and increasing northeast-southwest gradient was detected, with maximum concentration near the mouth of the stream present in the northeast side $(760 \pm 28 \mu \mathrm{M})$ (Fig. $4 \mathrm{~d})$. In contrast, the lowest concentration values were detected at the sampling point $23(49 \pm 8 \mu \mathrm{M})$ located in the south side of the lake. Moreover, concentrations higher than $300 \mu \mathrm{M}$ were also detected in the sediment situated among the islands in the south side.

Nitrite concentrations were low in all stations, in both water column and interstitial water, with values around 0.2 $\mu \mathrm{M}$ and $0.2-2 \mu \mathrm{M}$ for the water column and interstitial water, respectively.

Water nitrate concentration was lower than the sensitivity level of the method used. Nitrate concentration of interstitial water cannot be determined because a quick deterioration of the reductive column was caused.

\section{Relationship between the distribution of biomass and environmental variables}

The PCA showed that the first component axis accounted for $70 \%$ of the total variance of aquatic biomass data, while the sum of the two first component eigenvalues accounted for $90 \%$ of the total variance. On the other hand, the value of species-environment correlations obtained for the first component axis was 0.679 . This value works simi- 


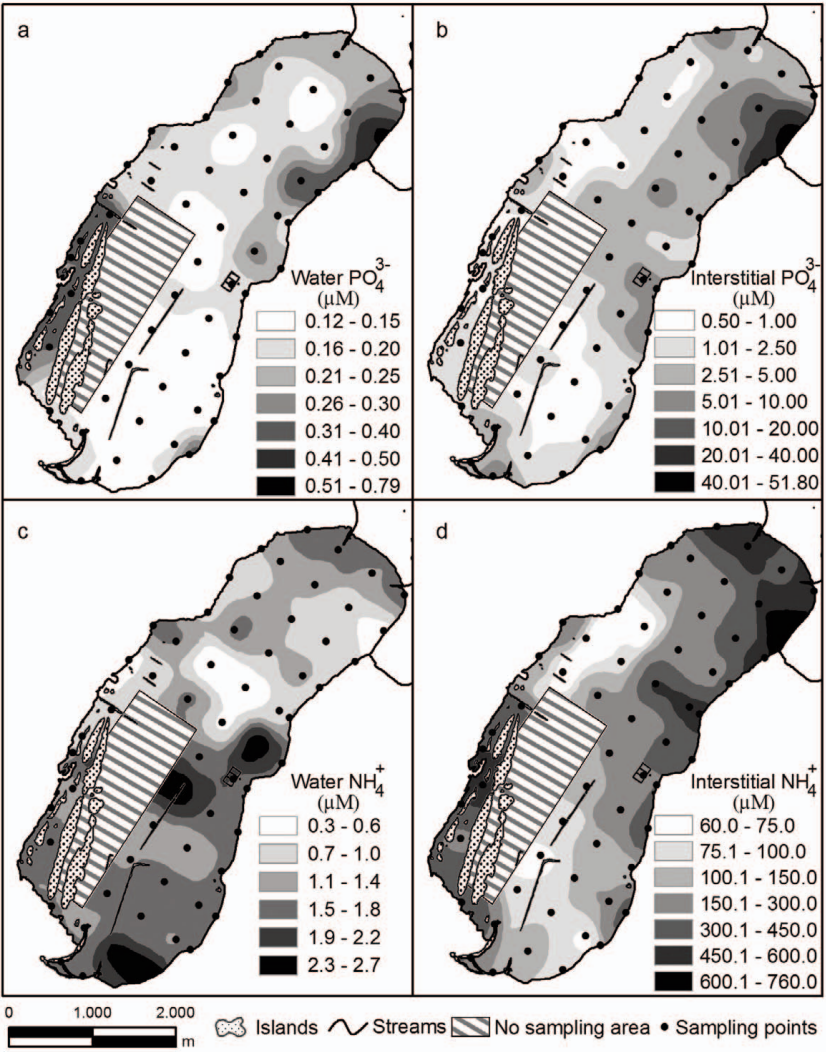

Fig. 4. Distribution of water concentration of soluble reactive phosphorus (SRP) (a), interstitial water concentration of SRP (b), water ammonium concentration (c) and interstitial water ammonium concentration (d) in the Fuente de Piedra lake.

larly to the correlation coefficient between any two variables (Legendre \& Legendre, 1998), so correlations between the first component axis for species data and some environmental variables have been shown.

A high load value (0.99; Table 1 ) was obtained for the $U$. flexuosa biomass data and first component axis, indicating a high importance of this species for the formation of that axis. In the same way, the second component axis seems to relate to $L$. papulosum and A. orientalis (load values of 0.71 and 0.4, respectively; Table 2). A distance biplot diagram with the sampling point plotted in a reduced-space of the first two component axes is shown in Fig. 5. Moreover, the projection of all species and environmental vectors correlated with these two component axes are also shown. This is the case of ammonium and SRP values of the sediment interstitial water, which were correlated with the first component axis (correlation coefficient values of 0.49 and 0.54 respectively; $\mathrm{P}<0.05)$.

Table 1. Eigenvalues and species-environment correlation for the first two principal component axes.

\begin{tabular}{lcc}
\hline & \multicolumn{3}{c}{ Axes } \\
\cline { 2 - 3 } Eigenvalues & 0.704 & II \\
Species-environment correlations & 0.680 & 0.191 \\
\hline
\end{tabular}

Table 2. Factor loadings of the different species for the first two principal component axes.

\begin{tabular}{lcc}
\hline & \multicolumn{3}{c}{ Axes } \\
\cline { 2 - 3 } Ulva flexuosa & $\mathbf{I}$ & II \\
Lamprothamnium papulosum & 0.99 & 0.01 \\
Althenia orientalis & 0.11 & 0.71 \\
Ruppia drepanensis & 0.04 & 0.40 \\
Ruppia maritima & 0.03 & 0.06 \\
\hline
\end{tabular}

The projection of the point ordination in the reducedspace of the first two axes was used to select a group of the sampling points, which appeared to be differently grouped from the rest of sampling points. In this way, sampling points highly influenced by the first component axis are plotted with diagram square symbols in the distance biplot. These sampling points showed high concentration of ammonium and SRP in the interstitial sediment water and showed the highest values of $U$. flexuosa biomass. In contrast, the sampling points scarcely influenced by the first component axis are plotted with asterisk symbols. This second group presented the lowest concentration of both already mentioned nutrients in the interstitial water sediment and the highest values of $L$. papulosum biomass. The rest of the sampling points are arranged following a gradient related to U. flexuosa biomass. Nevertheless, some sampling points with a low presence of the U. flexuosa could be differentiated from others by a lower U. flexuosa biomass and the highest values of $A$. orientalis (point symbols) or $R$. drepanensis (triangle symbols) biomass.

In order to obtain additional information for the interpretation of the axes, especially in the case of the second one, a Dutilleul's modified t-test was carried out. The biomass distribution of $U$. flexuosa and $A$. orientalis were negatively correlated $(\mathrm{R}=-0.337 ; \mathrm{P}<0.05)$. On the other hand, U. flexuosa was positively correlated with the concentration of ammonium $(0.590 \mathrm{P}<0.05)$ and $\mathrm{SRP}(\mathrm{R}=$ $0.541, \mathrm{P}<0.05)$ in the sediment water interstitial while

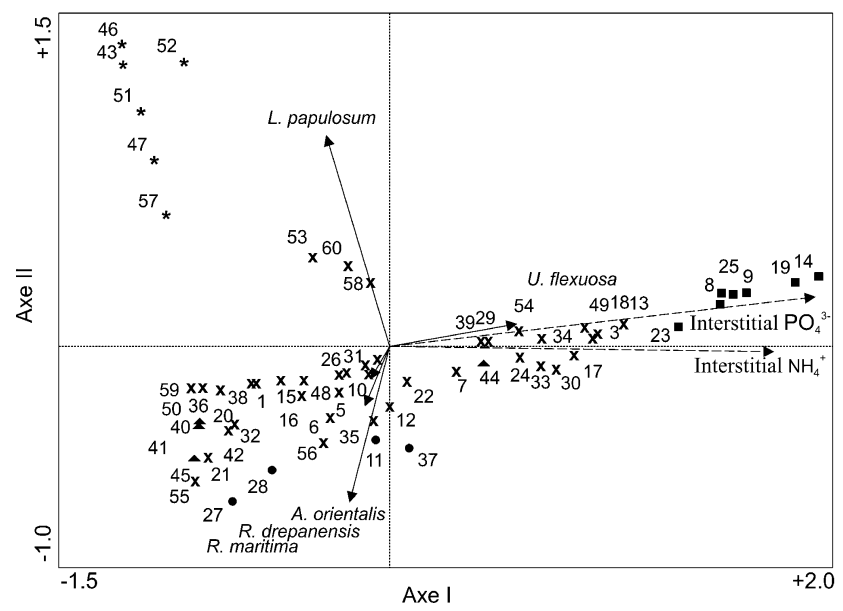

Fig. 5. Samples - species biomass PCA biplot. Environmental variables were used to interpret patterns extracted from all species biomass variation (indirect gradient analysis). 
L. papulosum was negatively correlated with the concentration of SRP $(\mathrm{R}=-0.320 ; \mathrm{P}<0.05)$ in the water, and positive correlated to the depth $(\mathrm{R}=387 ; \mathrm{P}<0.001)$. The biomass of $A$. orientalis was also positive correlated to the depth $(\mathrm{R}=0.315 ; \mathrm{P}<0.05)$.

Regarding the relationship between environmental variables, the different nutrient concentrations in the water column were positively correlated with those in the interstitial sediment water, except for the ammonium, which had no correlation. Moreover, the water ammonium and interstitial nitrate contents were not correlated to the rest of the analysed nutrients in both the water and the sediment, while the rest of the studied nutrients showed some correlation.

\section{Relationship between biomass and diaspore bank}

Seeds and oogonies density tended to increase with increasing biomass of the overlying submerged macrophyte, as reflected by the significant lineal regression found between the density of seed and the biomass of growing macrophytes (Fig. 6). Thus, the ratio diaspore/biomass can be estimated by using a regression analysis. The highest ratio corresponded to $L$. papulosum with estimated values of $5532 \pm 803$ oogonies $\mathrm{g}^{-1}$ biomass $\mathrm{DW}\left(R^{2}=0.888 ; \mathrm{P}<0.001\right.$; $\mathrm{n}=8$ ), while $A$. orientalis showed ratios of $537 \pm 110$ seeds $\mathrm{g}^{-1}$ biomass $\mathrm{DW}\left(R^{2}=0.800 ; \mathrm{P}<0.05 ; \mathrm{n}=8\right)$. The lowest ratio corresponded to $R$. drepanensis, with values of $58 \pm 5$ seeds $\mathrm{g}^{-1}$ biomass $\mathrm{DW}\left(R^{2}=0.959 ; \mathrm{P}<0.001 ; \mathrm{n}=8\right)$.

A high presence of characean oogonies were quantified at all studied points. These oogonies represented $77-100 \%$ of the total diaspore bank (seeds and oogonies). Nevertheless, $A$. orientalis did not reached $25 \%$ at any point, while the seed of $R$. drepanensis always represented less than $1 \%$, with the exception of the sampling point 50 where the estimated values of seeds represented $5 \%$ in total.

\section{DISCUSSION}

Our results indicate a different spatial distribution pattern of the species throughout the lake. There were zones of the lake where species grew together, but there were also some zones where a clear predominance of some species could be observed. Taking into account the predominant species it is possible to distinguish at least 5 zones in the lake. (1) In the northeast only the green algae U. flexuosa, was detected, with values of biomass higher than $150 \mathrm{~g}$ DW $\mathrm{m}^{-2}$. Similar biomass values of these and other green algae have been reported in a eutrophic estuary in the USA (Kinney \& Roman, 1988). Furthermore, the abundance of this alga has been reported in highly eutrophic sections of Tiber River basin in Italy (Ceschin \& al., 2010). (2) A. orientalis was the dominant macrophyte around the central area of the lake, while in the south (3) a monospecific bed of $L$. papulosum was observed. (4) R. drepanensis was the dominant macrophyte on the southeast shore and among the islands situated in the southwest of the lake. (5) The rest of the lake was characterized by a mixture of the different aquatic macrophytes commented above.

This well-defined distribution together with the high
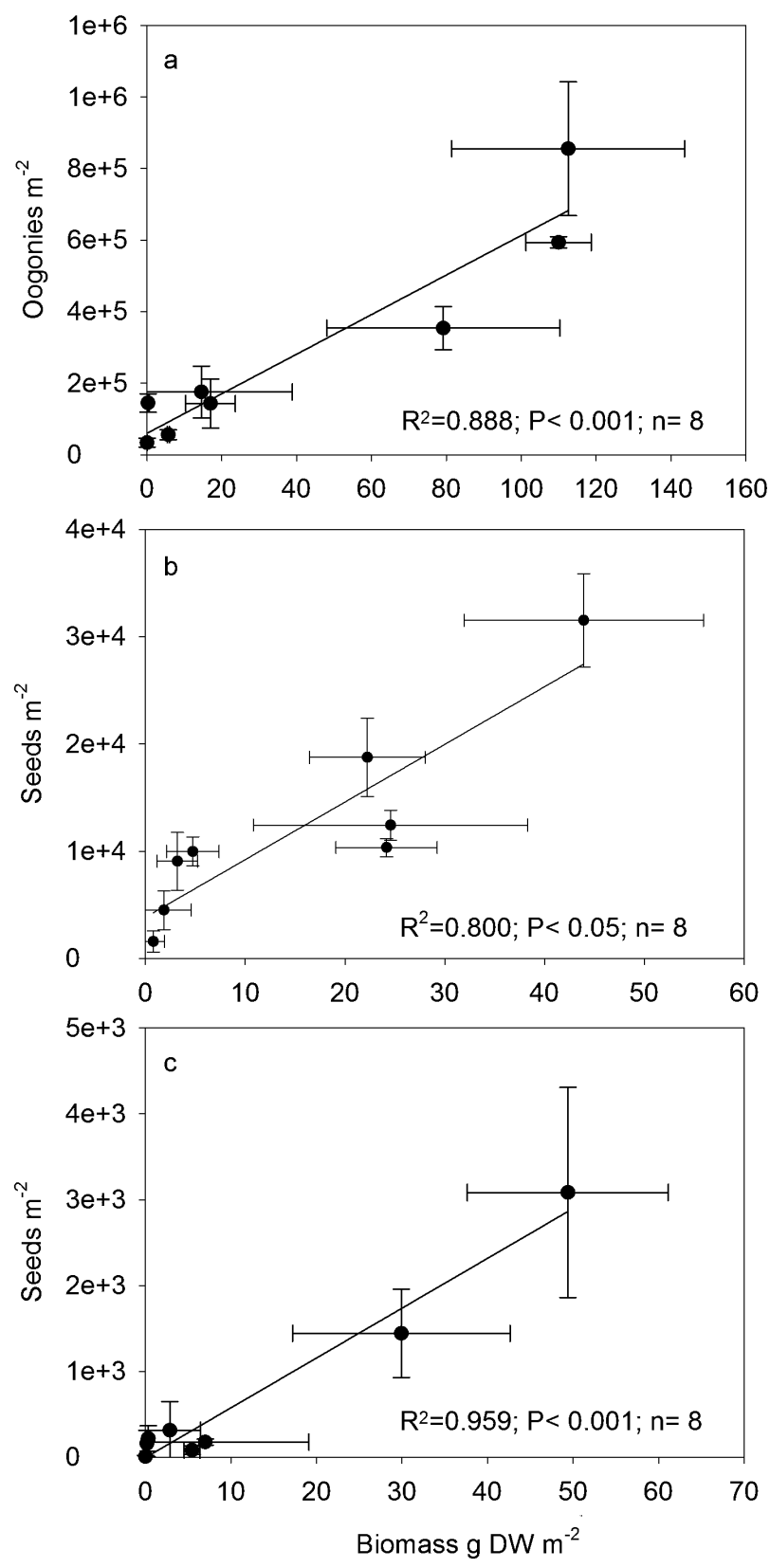

Fig. 6. Relationship between oogonies or seeds density and biomass of Charophytes (a), Althenia orientalis (b) and Ruppia drepanensis (c).

biomass values of the different submerged plants and charophytes present in the lake suggest the importance of this lake for the conservation of the submerged macrophytes growing in these habitats.

The multivariate analysis indicated that the first principal component explained $70 \%$ of the distribution variability of macrophyte biomass in the lake, while if the two first axes are taken together the explained variability was $90 \%$. The formation of the first axis depended on U. flexuosa biomass. The abundance of this species has already been proposed as valid bio-indicators of the water eutrophication grade (Ceschin \& al., 2010). In addition, this axis was positively correlated with interstitial concentra- 
tion of ammonium and SRP. In contrast, the formation of the second component axis was largely influenced by $L$. papulosum. The biomass of this species was positively correlated with the lake depth and negatively correlated with interstitial ammonium and SRP concentration. In this way, low phosphorus concentration seems to be a necessary condition for growth of L. papulosum (Martínez-Taberner \& Moya, 1991) and other Charophytes (Forsberg, 1964). On the other hand, the formation of the second axis was also influenced to a lower extent by $A$. orientalis. The biomass distribution of this species showed positive correlation to the lake depth, and was negatively correlated to interstitial ammonium.

Taking this into account, the first component axis could be identified as an eutrophic gradient through the lake, in the northeast-southwest direction. In this way, the most eutrophic area would be located in the northeast, near the mouth of the creek where the highest values of U. flexuosa biomass were obtained. An accumulation of alga biomass in this part of the lake due to the wind action could be rejected, since the most frequent winds took place from South-Southwest to North-Northwest direction (data not shown).

The less eutrophic area would be situated close to the central part of the south side of the lake, where L. papulosum grew forming a dense monospecific bed.

The origin of the nutrient contamination may be related to the discharge of nutrient-rich water from a stream in the north-eastern part of the lagoon (Charcón stream). Although the input of nutrient-rich water was specifically important before the 90's (Vargas \& al., 1983), after these years this stream continued flowing into the lagoon waters rich in nutrients (García-Jiménez, 1991; Conde-Álvarez, 2001).

On the other hand, internal release of phosphorus from the sediment could have a long-term effect, even after the external input reduction (Søndergaard \& al., 2007). Moreover, sediment disturbance due to trampling and feeding of water birds, such as flamingos, could also produce a water turbidity increase and nutrient release from sediment into the water column (Comín \& al., 1994; Glassom \& Branch, 1997). The high density of flamingos often present in the Fuente de Piedra lake could also provoke such impacts in the sediment. Nevertheless, no data about the effect of flamingo activity on the sediment and submerged macrophytes of this lake are available.

The correlation between the first component axis with interstitial ammonium and SRP, and the absence of correlation to nutrient water concentration could be due to the uptake of water nutrients by primary producers, especially $U$. flexuosa. Conde-Álvarez (2001) reported a negative correlation between biomass of these algae and the water concentration of $\mathrm{NO}_{3}, \mathrm{PO}_{4}^{3+}$, and especially of $\mathrm{NH} 4+$, throughout the time.

Disappearance of macrophytes in shallow water systems, both coastal and inland, has been linked to nutrient enrichment, due to human activity (Moss, 1990). Change from a state dominated by submerged macrophytes to turbid states dominated by phytoplankton has been described in shallow lakes affected by increasing nutrient loading (Bayley \& Prather, 2003). In turbid states, phytoplankton produces a shadow effect which would reduce the light availability for submerged macrophytes (Carter \& Rybicki, 1990; Santamaría \& al., 1996). In the case of Fuente de Piedra lake this shadow effect, related to eutrophication phenomena, would be mostly due to the growth of the filamentous algae $U$. flexuosa. A similar phenomenon has been reported in a shallow alkaline mill-pool which had about $60 \%$ of its surface covered by filamentous algae in forms of floating or benthic mats (Irfanullah \& Moss, 2004).

In addition, nutrient enrichment could directly affect physiology growth and reproduction of aquatic macrophytes. Santamaría \& al. (1994) showed that high levels of interstitial ammonia inhibited growth of $R$. drepanensis growing under laboratory conditions. Similar results have been described for Chara connivens when the concentration of ammonia exceeded $10 \mathrm{mg} \mathrm{NH}_{4}^{+} \mathrm{l}^{-1}$. It is noteworthy that this concentration is lower than that measured in some areas of Fuente de Piedra lake. On the other hand, Santamaría \& al. (1996) suggested that the beginning of flowering could be related to a decrease of nitrogen availability. Nitrogen enrichment could delay the flowering, which could lead to the species were unable to complete their reproduction before the lake dries out. In the same way, a seed germination inhibition due to high ammonia concentration has also been suggested (Perrow \& al., 1994).

Beyond eutrophication factor, the second principal component axis could be related to depth gradient, although its meaning is quite more complex of understanding than the first axis. In relation to depth, water residence time and therefore salinity, during both the early stages of filling and the length of the final phase of drying would be related. Although higher sand content was obtained where L. papulosum formed a dense meadow, no correlation was found between its biomass distribution and any sediment size fraction. In contrast, $A$. orientalis biomass was negatively correlated to the sand content. Influence of sediment on plant establishment has already been reported (Selig \& al., 2007). This could be related to the influence of texture and porosity in the roots, with regard to the subjection of plants (Schutten \& al., 2005) and nutrient uptake (Wijck \& al., 1994).

Positive correlations between seeds or oogonies and biomass for the different species were found. Similar results have been reported for angiosperms (Grillas \& al., 1993) and characeae (Acosta \& al., 1999). This positive correlation could indicate a positive feed-back of submerged macrophyte population itself (Santamaría \& Vierssen, 1995). In this way, dense macrophyte beds will produce a dense diaspore bank and this will determine abundant germination when ideal hydrological conditions take place, establishing a new dense macrophyte bed.

The composition and structure of the submerged aquatic macrophyte report in this study corresponds to the state of the lake in a wet year. This composition and structure will change in years with a lower amount of precipitations. Nevertheless, both composition and structure would always be conditioned by the composition of the diaspore bank, which are, in turns, deeply related to the high production of seed during wet years. 
The eutrophication gradient described for this lake could be breaking the above-mentioned positive feedback of submerged macrophytes, as they cannot complete their life cycle. Persistence of eutrophication conditions could lead to a progressive depletion of diaspore bank with negative consequences for the submerged macrophyte communities and other components of this peculiar system. Nevertheless, studies based on a larger temporal scale are necessary in order to estimate the system behaviour during years of lower water content and evaluate the consequences of the eutrophication from a temporal perspective.

The results reported in this study stress the importance of our knowledge of the system spatial variability as the basis for the selection of appropriate sampling sites for monitoring this kind of system. Thus, any monitoring program of this lake should to take into account at least the 5 zones mentioned above, as well as, the eutrophic gradient in the northeast-southwest direction.

\section{ACKNOWLEDGMENTS}

This work was supported by Consejería de Medio Ambiente - Junta de Andalucía (Project 807/03.1169), the Ministry of Education and Science of Spain (Project CICYT AMB97-1021-C02-01; CGL2008-05407-C0301) and by the Junta de Andalucía to the research group RNM-295 and RNM-115. Charo Velasco and Ángeles Arrebola collaborated with us in the fieldwork.

\section{REFERENCES}

Acosta, L.W., Sabbatini, M.R., Fernández, O.A. \& Burgos, M.A. 1999. Propagule bank and plant emergence of macrophytes in artificial channels of a temperate irrigation area in Argentina. Hydrobiologia 414: 1-5.

Anderson, M.J., Connell, S.D., Gillanders, B.M., Diebel, C.E., Blom, W.M., Saunders, J.E. \& Landers, T.J. 2005. Relationships between taxonomic resolution and spatial scales of multivariate variation. Journal of Animal Ecology 74: 636-646.

Baker, M.E., Weller, D.E. \& Jordan, T.E. 2006. Improved methods for quantifying potential nutrient interception by riparian buffers. Landscape Ecology 21(8): 1327-1345.

Bayley, S.E. \& Prather, C.M. 2003. Do wetland lakes exhibit alternative stable states? Submersed aquatic vegetation and chlorophyll in western boreal shallow lakes. Limnology and Oceanography 48(6): 2335-2345.

Carter, V. \& Rybicki, N. 1990. Light attenuation and submersed macrophyte distribution in the tidal Potomac River and estuary. Estuaries 13(4): 441-452.

Ceschin, S., Zuccarello, V. \& Caneva, G. 2010. Role of macrophyte communities as bioindicators of water quality: Application on the Tiber River basin (Italy). Plant Biosystems 144(3): 528-536.

Cirujano, S., Velayos, M., Castilla, F. \& Gil, M. 1992. Criterios botánicos para la valoración de las lagunas y bumedales españoles (Peninsula Ibérica y las Islas Baleares). Colección Técnica ICONA. Madrid.

Comín, F.A., Herrera-Silveira, J.A. \& Martín, M. 1994. Flamingo footsteps enhance nutrient release from the sediment to the water column. In: Faragó, S.A. \& . Kerekes, J. J. (eds), Wetlands International Publicaton 43: 211-227. Sopron.

Conde-Álvarez, R.M. 2001. Variaciones espacio-temporales y ecofisiológicas de los macrófitos acuáticos de la laguna atalasohalina de Fuente de Piedra (Sur de la Península Ibérica). Universidad de Málaga.

Feldmann, T. \& Nõges, P. 2007. Factors controlling macrophyte distribution in large shallow Lake Võrtsjärv. Aquatic Botany 87: 15-21.

Fernández, J.A., Niell, F.X. \& Lucena, J. 1985. A rapid and sensitive automated determination of phosphate in natural water. Limnology and Oceanography 30(1): 227-230.

Foden, J. 2007. Assessment metrics for littoral seagrass under the European Water Framework Directive; outcomes of UK intercalibration with the Netherlands. Hydrobiologia (579): 187-197.
Forsberg, C. 1964. Phosphorus, a maximum factor in the growth of characeae. Nature 201:517-518.

Fraser, L.H. \& Keddy, P.A. 2005. The world's largest wetlands: Ecology and conservation. Cambridge University Press, Cambridge.

García Jiménez, C. 1991. Estudio de un medio acuático fluctuante: la laguna atalasobalina de Fuente de Piedra (Málaga). Universidad de Málaga.

Glassom, D. \& Branch, G.M. 1997. Impact of predation by greater flamingos Phoenicopterus ruber on the meiofauna, microflora, and sediment properties of two southern African lagoons. Marine Ecology Progress Series 149: 1-12.

Grillas, P., García-Murillo, P., Geertz-Hansen, O., Marbá, N., Montes, C., Duarte, C.M., Tan Ham, L. \& Grossmann, A. 1993. Submerged macrophyte seed bank in a Mediterranean temporary marsh: abundance and relationship with established vegetation. Oecologia 94: 1-6.

Irfanullah, H. \& Moss, B. 2004. Factors influencing the return of submerged plants to a clear-water, shallow temperate lake. Aquatic Botany 80: $177-191$.

Kinney, E. \& Roman, C. 1988. Response of primary producers to nutrient enrichment in a shallow estuary. Marine Ecology Progress Series 163: 89-98.

Legendre, P. \& Legendre, L. 1998. Numerical Ecology. Elsevier, Amsterdam.

Martín, J. 1999. Desarrollo y aplicación del nuevo catálogo de especies amenazadas de la comunidad de Castilla-La Mancha. Conservación Vegetal 4:5-6.

Martínez-Taberner, A. \& Moya, G. 1991. Water chemistry tolerance of charophytes in a Mediterranean coastal marsh. Nova Hedwigia 52: 1-2.

McElarney, Y.R. \& Rippey, B. 2009. A comparison of lake classifications based on aquatic macrophytes and physical and chemical water body descriptors. Hydrobiologia 625: 195-206.

Moe, S.J., Dudley, B. \& Ptacnik, R. 2008. REBECCA databases: experiences from compilation and analyses of monitoring data from 5,000 lakes in 20 European countries. Aquatic Ecology 42: 183-201.

Moss, B. 1990. Engineering and biological approaches to the restoration from eutrophycation of shallow lakes in which aquatic plant communities are important components. Hydrobiologia 200-201: 367-378.

Penning, W.E., Dudley, B., Mjelde, M., Hellsten, S., Hanganu, J., Kolada, A., van den Berg, M., Poikane, S., Phillips, G., Willby, N. \& Ecke, F. 2008a. Using aquatic macrophyte community indices to define the ecological status of European lakes. Aquatic Ecology 42: 253-264.

Penning, W.E., Mjelde, M., Dudley, B., Hellsten, S., Hanganu, J., Kolada, A., van den Berg, M., Poikane, S., Phillips, G., Willby, N. \& Ecke, F. 2008b. Classifying aquatic macrophytes as indicators of eutrophication in European lakes. Aquatic Ecology 42: 237-251.

Pérez-Ruzafa, A., Marcos, C., Pérez-Ruzafa, I.M., Barcala, E., Hegazi, M.I. \& Quispe, J. 2007. Detecting changes resulting from human pressure in a naturally quick-changing and heterogeneous environment: Spatial and temporal scales of variability in coastal lagoons. Estuarine, Coastal and Shelf Science 75: 175-188.

Perrow, M.R., Moss, B. \& Stansfield, J. 1994. Trophic interactions in a shallow lake following a reduction in nutrient loading: a long-term study. Hydrobiologia: 43-52.

Pokorný, J. \& Kevět, J. 2004. Aquatic Plants and lake Ecosystem. In: Patrick E. O'Sullivan \& Colin, S., The Lakes Handbook: Limnology and limnetic ecology: 309-340. Blackwell Publishing Maldel (USA).

Porta, J. 1986. Técnicas y experimentos en edafología. Colegi oficial d'Enginyers Agrònomos de Catalunya, Barcelona.

Ramsar. 2007. Inventory, assessment, and monitoring: An Integrated Framework for wetland inventory, assessment, and monitoring. Ramsar handbooks for the wise use of wetlands, 3 rd edition, vol. 11. Ramsar Convention Secretariat, Gland, Switzerland.

Rosenberg, M.S., \& Anderson, C.D. 2011. PASSaGE: Pattern Analysis, Spatial Statistics and Geographic Exegesis. Version 2. Methods in Ecology and Evolution 2(3): 229-232.

Santamaría, L., Dias, C. \& Hootsmans, M. 1994. The influence of ammonia on the growth and photosynthesis of Ruppia drepanensis Tineo from Doñana National Park (SW Spain). Hydrobiologia 276(2): 219-231.

Santamaría, L. Montes, C. \& Hootsmans, M.J.M. 1996. Influence of environmental parameters on the biomass development of Ruppia drepanensis populations in Doñana National Park: The importance of con- 
ditions affecting the underwater light climate. International Journal of Salt Lake Research 5: 157-180.

Santamaría, L. \& Vierssen, W.V. 1995. Predicting the impacf of eutrophication stress on the survival of submerged vegetation in shallow temporaly lakes. 6th International Conference on the conservation and management of lakes and reservoirs: 777-780.

Schutten, J., Dainty, J. \& Davy, A.J. 2005. Root anchorage and its significance for submerged plants in shallow lakes. Journal of Ecology 93(3): 556-571.

Selig, U., Schubert, M., Eggert, A., Steinhardt, T., Sagert, S. \& Schubert, H. 2007. The influence of sediments on soft bottom vegetation in inner coastal waters of Mecklenburg-Vorpommern (Germany). Estuarine Coastal and Shelf Science 71: 241-249.

Shinn, M.B. 1945. A colorimetric method for the determination of nitrite. Industrial and Engineering Chemistry, Analytical Edition 13: 33-35.

Slawyk, G. \& MacIsaac, J.J. 1972. Comparison of two automated ammonium methods in a region of coastal upwelling. Deep-Sea Research 19: 521-524.

Sokal, R.R. \& Rohlf, F.J. 1995. Biometry. Freeman \& Company, New York.

Søndergaard, M., Jeppesen, E., Lauridsen, T., Skov, C., Van Nes, E., Roijackers, R., Lammens, E. \& Portielje, R. 2007. Lake restoration suc- cesses, failures and long-term effects. Journal of Applied Ecology 44: 1095-1105.

Søndergaard, M., Johansson, L.S., Lauridsen, T.L., Jørgensen, T.B., Liboriussen, L. \& Jeppesen, E. 2010. Submerged macrophytes as indicators of the ecological quality of lakes. Freshwater Biology 55: 893-908.

Turner, R.K., van den Bergh, J.C.J.M., Söderqvist, T., Barendregt, A., van der Straaten, J., Maltby E. \& van Ierland, E.C. 2000. Ecological-economic analysis of wetlands: scientific integration for management and policy. Ecological Economics 35: 7-23.

Vargas, J.M., Blasco, M. \& Antúnez, A. 1983. Los vertebrados de la laguna de Fuente de Piedra (Málaga). Monografías ICONA 28: 1-228.

Wijck, C.P., Grillas, C.J. \& de Groot, L.T. 1994. A comparison between the biomass production of Potamogeton pectinatus L. and Myriophyllum spicatum L. in the Camargue (southern France) in relation to salinity ans sediment characteristics. Vegetatio 113: 171-180.

Wood, E.D., Armstrong, F.A.J. \& Richards, F.A. 1967. Determination of nitrate in sea water by cadmium-copper reduction to nitrite. Journal of the Marine Biological Association 47: 23-31.

Associate Editor: Santos Cirujano

Received: 19-I-2012

Accepted: 14-IV-2012 
